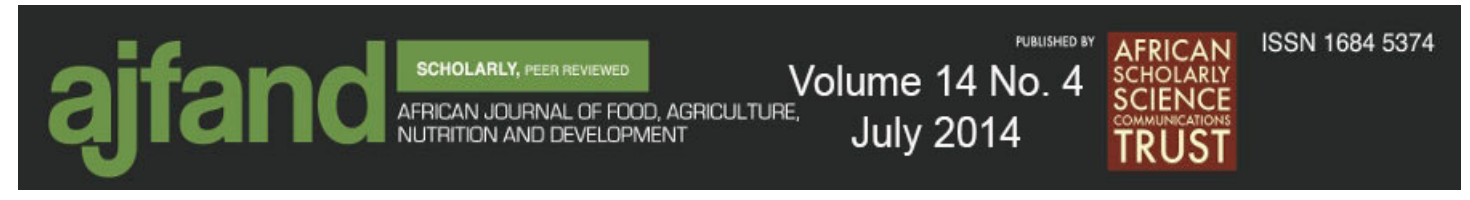

\title{
KNOWLEDGE, ATTITUDE AND INTENDING PRACTICE OF FEMALE UNDERGRADUATES ABOUT BREASTFEEDING
}

\section{Ogunba $\mathrm{BO}^{1 *}$ and EO Agwo ${ }^{1}$}

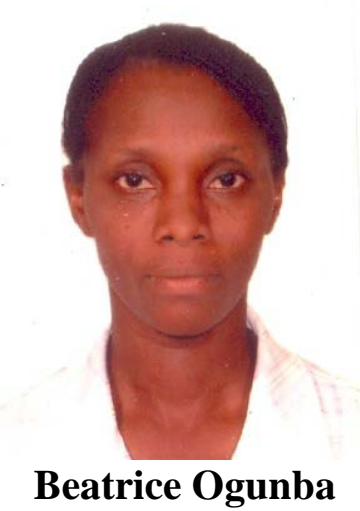

*Corresponding author’s email: ogunbabeatrice@yahoo.com

${ }^{1}$ Department of Family, Nutrition and Consumer Sciences, Faculty of Agriculture, Obafemi Awolowo University, Ile Ife, Nigeria 


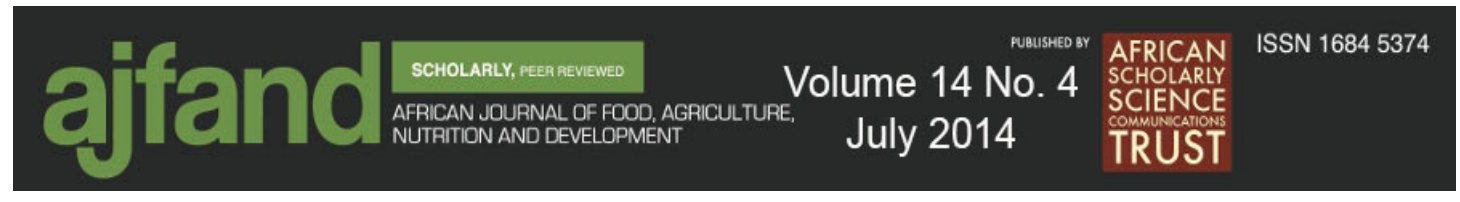

\section{ABSTRACT}

The recommendation by the World Health Organization (WHO) is that infants should be fed exclusively on breast milk for the first 6 months, but the rate of exclusive breastfeeding $(\mathrm{EBF})$ has been on the decline in Nigeria. The study determines knowledge, attitude and intending practice of unmarried female undergraduates about breastfeeding (BF). Two hundred females were selected using the simple random sampling procedure. Interview schedule was used to obtain information on socioeconomic characteristics, knowledge, attitude and intending practices of EBF of Obafemi Awolowo University Ile Ife, Nigeria. Knowledge and attitudes on BF were determined using a three and five point Likert Scale, respectively. Data was described using percentages, frequency counts and regression. Sixty percent of the respondents were between the ages of 21 and 24years and more than half are four hundred level students (54.5\%). Knowledge on the term EBF is misconstrued as BF for 12 months by $33 \%$ of the respondents. Women intend to initiate BF between the first $0-6$ hour of birth (65\%) and breast feed on request (62.5\%). However, 61\% may not practice EBF because of their jobs, will introduce infant formula or water during the first six months and 38.3\% will not breast feed in public. Women intend to terminate BF at 3 months (5.0\%), 6 months (16.5\%), 1 year (50.5\%) and 2 years (28.0\%) because of their health status (54.0\%). Knowledge about BF was average (94\%) and attitude was neutral (77.4\%).Women intend to manage EBF during working hours by having fixed feeding schedules (14.0\%) and using expressed breast milk (16.0\%). About 34.5\% of respondents will not use expressed breast milk because of fear of contamination (42.0\%) and their health (36.3\%), 6.0\% expressed the opinion that EBF is not possible. Major influence on BF decisions includes maternal health (59.7\%), maternal jobs (54.4\%), husbands (34.5\%), mother (24.8\%), and mothers in law (17.5\%). Regression analysis revealed that knowledge $(b=-0.025)$ has a negative significant relationship with duration of EBF of mothers at $p<0.05$. It is concluded that women lacked understanding of the $\mathrm{BF}$ recommendations, duration of $\mathrm{EBF}$, have average knowledge and neutral attitude towards EBF. It is recommended that child health matters should be taught not only in the medical schools, but special courses should be offered to increase knowledge on appropriate recommendations on BF practices for all students.

Key words: undergraduate, attitude, knowledge, practice, breastfeeding 


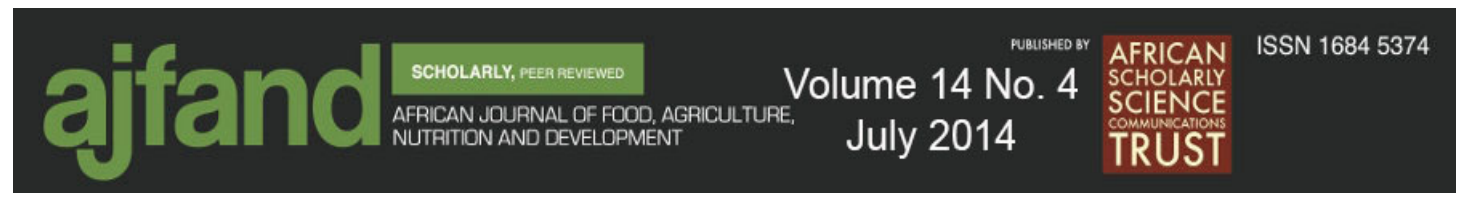

\section{INTRODUCTION}

Breastfeeding is the normal, natural way to feed infants, and is part of laying the foundation for a healthy life from infancy and childhood. Breast milk easily absorbed and has a low solute load, and an increased availability of minerals, vitamins, and proteins. It has been estimated that exclusive breastfeeding (EBF) reduces infant mortality rates by up to $13 \%$ in low-income countries [1]. Studies [2, 3] indicate that breastfed infants have fewer ear and respiratory tract infections, diarrheal illnesses, and atopic skin disorders. Early introduction of breast milk substitution and cow's milk have been shown to increase the risk of type 1 diabetes later in life [4].

The World Health Organization (WHO) recommends that infants be fed exclusively on breast milk from birth to six months of age. While exclusive breastfeeding rate is on the increase globally and in sub-Saharan Africa, it has continuously been on the decline in Nigeria. The Nigerian Demographic and Health Survey [5] estimated the level of exclusive breastfeeding in the country at 13 percent in 2008 which is a drop from the 17 percent estimated in 2003.

Nigeria has poor nutritional indices which indicate 14\% low birth weight, $13 \%$ EBF, $14 \%$ stunting and $27 \%$ underweight [6]. Nigeria comes third after India and China in the world list of greatest number of undernourished children and is currently one of the two African countries listed among the twenty responsible for the $80 \%$ of global malnutrition. Malnutrition is particularly severe in the Northern region of the country [7].

The factors responsible for the sharp decline include reduced baby friendly hospital initiative programming, inadequate training, poor enforcement of the code of marketing of breast milk substitutes, and weakened compliance with the ten steps in accredited maternities. Mothers who had four or more antenatal visits were significantly more likely to engage in EBF [8]. Studies have revealed that a mother's level of education has a positive impact on her knowledge and how she deals with child health care issues [9]. Breastfeeding decisions and practices are influenced by multiple factors including knowledge, attitudes and beliefs, as well as socio-cultural and physiological factors [10-13]. Therefore, the mother's knowledge about child care influences the nature and quality of care that is given to the child [14]. There seems to have been little improvement in the knowledge of mothers on common child health matters over the years in spite of the many years of girls' education in the country. Al Ayed studies revealed that no statistically significant correlation was evident between mothers' knowledge of child health related matters and level of education, age, or number of children [9]. Research has repeatedly found that women's pre-birth 


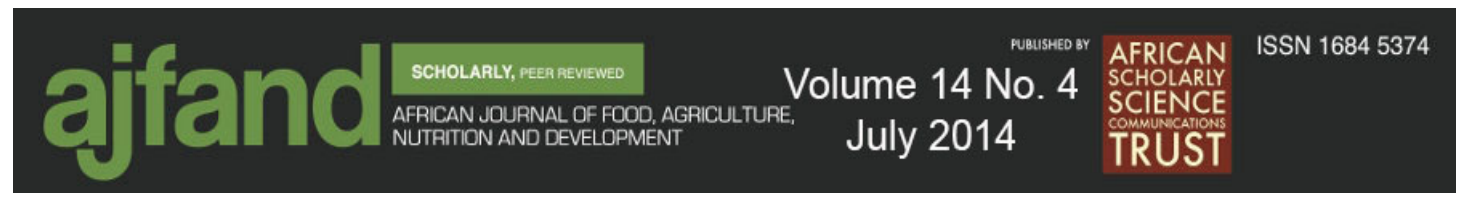

breastfeeding intentions are a good predictor of the actual duration of breastfeeding [15-17]. The decision to breast feed or to bottle-feed was most often made before pregnancy [18]. The study, therefore, investigated the knowledge, attitude and intending practice of unmarried female undergraduate students about EBF.

\section{METHODOLOGY}

The study was carried out amongst University undergraduates of Obafemi Awolowo University Ile Ife Nigeria. The purpose of the study was to examine the attitude, knowledge and intending practice of female University undergraduates toward BF. Data were gathered for 200 women that were randomly selected from the University community. A structured interview schedule was used to solicit information on socio economic characteristics, knowledge, attitude and intended practices of breastfeeding. Knowledge and attitude were assessed with positive and negative statements on BF practices. A three point and five point Likert scale was used to determine knowledge and attitude, respectively. The 3 point Likert scale had a score of 3 for agree, 2 for $I$ don't know and 1 for disagree for positive statements and vice versa for negative statements. Attitude was measured on 5 point scale with Strongly agree( 5 points), agree(4 points), 3 points for I don't know and 2 and 1 point respectively for disagree and strongly disagree for positive statement and the reverse for negative statements. Data processing and analysis were done using frequency counts, percentage, correlation and logistic regression analysis using SPSS package 16.0.

\section{ETHICAL ISSUE}

The research was approved by the Department of Family, Nutrition and Consumer Sciences for the University Research Committee. Respondents consent was obtained verbally after given explanation about the purpose of the research.

\section{RESULTS}

\section{Socio economics characteristics}

As presented in Table 1, majority (60.0\%) of the respondents were between the ages of 21 and 24 with a mean of 21.3 \pm 2.2 , single (91.0\%) and were Christians (87.5\%). A total of 73 (36.5 \%) of them have $\$ 31$ - \$60 as monthly allowance, 39.5\% are Science students and $54.5 \%$ were Part four students of the University.

\section{Knowledge on breastfeeding}

Knowledge about breastfeeding was examined and the results in Table 2 revealed that the term EBF is misconstrued as breastfeeding for 12 months by $33 \%$ of the 


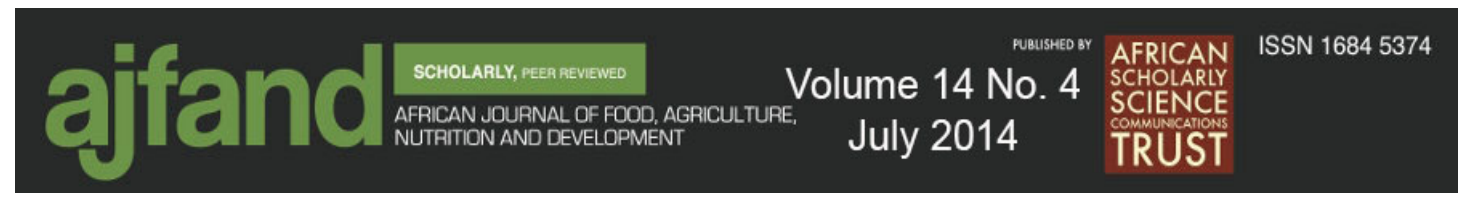

respondents, $25.0 \%$ and $16.5 \%$ would give water and infant formula as part of EBF. Knowledge about the immunological protection of colostrum was not known (22\%) while $27.5 \%$ do not have the knowledge that mothers with HIV can breast feed. Mothers disagreed on the advantages of breastfeeding as it allows intimacy between mother and child (87.5\%) and its beneficial effect on mothers (59.0\%). Overall knowledge about breastfeeding was low (3.5\%), average (94\%) and high (2.5\%).

\section{Attitude toward breastfeeding}

Attitude toward breastfeeding on Table 3 shows that most of the respondents will not practice exclusive breastfeeding since $61.5 \%$ will combine infant formula with breast feeding. One third (39.5\%) cannot breast feed in public and $7.0 \%$ can only if they do not have enough money for infant formula. Also 54.0\% agreed that babies should be given breast milk on request. Eighty seven percent agreed that it is not a waste of time to practice EBF and 6.0\% sees it as an outdated fashion. Attitude toward exclusive breast feeding was, however, negative (14.6\%), neutral (77.4\%) and positive (8.0\%).

\section{Intending practice of breastfeeding}

Results on Table 4 revealed that most of the respondents will initiate breastfeeding between 0-6 hours of birth. Few will give water and concoction and 33.0\% intend to practice EBF assuming it is for 12 months. Duration of EBF varied from 3months (11.0\%), 6 months (40.0\%), 1 year $(25.0 \%)$ and 2 years $(14.0 \%)$ while respondents intend to terminate breastfeeding at 3 months (5.0\%), 6 months (16.5\%), 1 year $(50.5 \%)$ and 2 years $(28.0 \%)$. The major reason anticipated for termination is for health reasons $(37.9 \%)$.

\section{Exclusive breastfeeding at work}

As presented in Table 5, intending mothers plan to manage EBF at work by expressing breast milk (16.0\%), have fixed feeding schedules (14.0\%), give excuses at work (13.0\%) and practice mixed feeding (0.5\%). Also 34.5\% of respondents will not use expressed breast milk because of their health (36.3\%), education (7.3\%), social status (4.3\%) and fear of contamination (42.0\%).

\section{Influence on breastfeeding decision}

Results in Table 6 revealed that nine factors may influence breast feeding decision. These include maternal health (59.7\%), maternal jobs (54.4\%), husbands (34.5\%), mother (24.8\%), and mothers inlaw (17.5\%). Others are education (19.4\%), friends (10.2\%) and inadequate milk (19.4\%). 


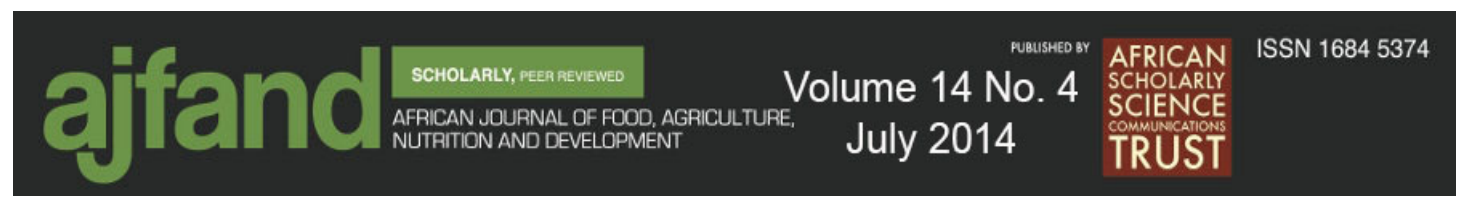

Socio economics characteristics, knowledge and attitude of respondents

Results in Table 7 revealed that Medical and Science students had better knowledge and more positive attitudes towards exclusive breastfeeding. Students in the sciences had positive attitude and high knowledge when compared to others in the arts, social sciences and education at $\mathrm{p}<0.000$. Also women from monogamous households had positive attitude and greater knowledge about breastfeeding practices at $\mathrm{p}<0.002$.

\section{DISCUSSION}

Breastfeeding is a practice embraced by Nigerian mothers since almost every newborn is breastfed. However, EBF is not well practiced for several reasons which include misconception about the term EBF and knowledge about the practice. This is also found in Shirima et al. [19]'s study in Tanzania that EBF is not well practiced due to the lack of knowledge about the concept. Inadequate maternal knowledge about feeding practices is often a greater determinant of malnutrition than lack of food [20]. It is recommended that babies be exclusively breast fed with breast milk which implies no feeding with other liquids (including water) or food for the first 6 months of life [21]. The study found out that respondents had limited understanding of the term "exclusive breastfeeding" because $33 \%$ of the respondents assumed that EBF is for 12 months and half of the respondents will give water to children as part of the EBF practices as shown in Table 2. The recommendation by WHO is that children be put to the breast immediately or within one hour after birth [22]. Early breastfeeding practices determine the successful establishment and duration of breastfeeding. Intending mothers will initiate BF between 0 and 6 hour after birth, 21.5\% will initiate the second day (as shown in Table 4) and most will not practice EBF. Mothers who were aware of the recommendation were 5.6 times more likely to intend to breast feed exclusively for six months [23]. Amongst mothers that may practice EBF, $16.0 \%$ intend to use expressed milk while others may have feeding schedule for babies, which may eventually influence mixed feeding of the infant. About $31 \%$ will feed infant formula with feeding bottle as against infant feeding recommendation. Bottlefeeding is not recommended because unhygienic conditions and poor formula preparation associated with bottle-feeding can put the child at greater risk of illness and malnutrition [24]. Bottle-feeding is thus perceived as the modern way and breastfeeding as old fashioned and inconvenient. Half of the respondents will terminate when the child is one year and only $28 \%$ will follow the two years' recommendation [22].

The course of study of women influenced their knowledge and attitude concerning breastfeeding. Termination of BF may be determined by mother's health and education because most of the women have it in plan to go for further study after 


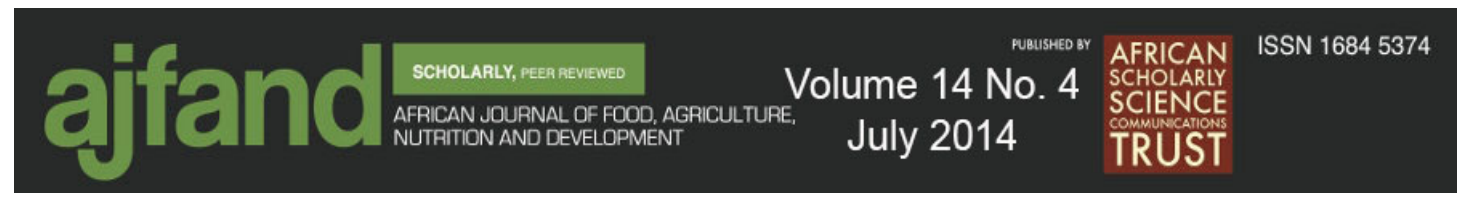

marriage. Female education has often been described as one of the strongest determinants of the practice of EBF [25]. Women lacked understanding of the BF recommendations, duration of $\mathrm{EBF}$, have low knowledge and indifference attitude towards EBF. Breastfeeding practices and decisions may be influenced by the health of the mother, job, husband and mother. Others include mother in-law, friend, social status and education.

\section{CONCLUSION}

The wrong knowledge about exclusive breastfeeding recommendation, low knowledge and the indifference of unmarried women can result in the reduction in the number of children that are exclusively breastfed, reduction in use of prelacteal feeding, encouragement of mixed feeding and a reduced duration of EBF and early termination of breastfeeding. Awareness and increased knowledge about the recommendations of exclusive breastfeeding practices should be a key goal for nutrition educators for both married and unmarried women. Knowledge on child health matters should be taught in schools as special courses, not only in the medical schools, but in all tertiary institutions. These may be important strategies to increase breastfeeding rates, duration and adoption of appropriate breastfeeding practices. 


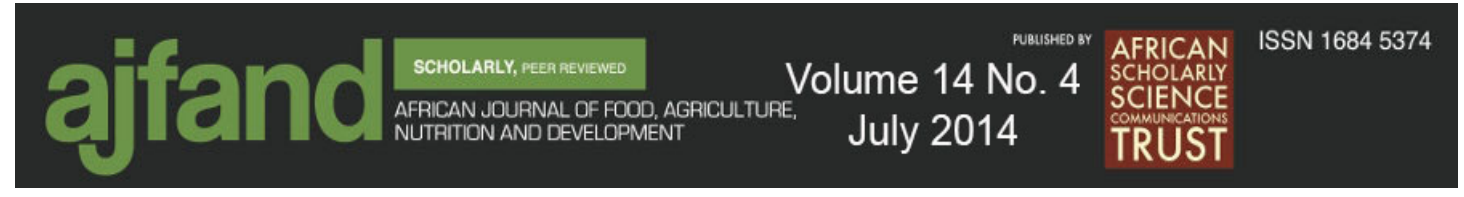

Table 1: Socio economics characteristics of respondents

\begin{tabular}{|c|c|c|}
\hline Variables & \begin{tabular}{|l|} 
Frequency(200) \\
\end{tabular} & $\%$ \\
\hline 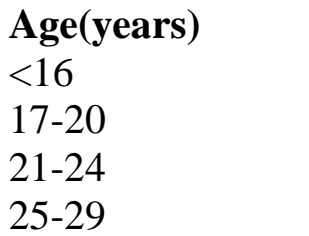 & $\begin{array}{c}6 \\
124 \\
120 \\
15\end{array}$ & $\begin{array}{c}1.5 \\
31.0 \\
60.0 \\
7.5\end{array}$ \\
\hline $\begin{array}{l}\text { Marital Status } \\
\text { Single } \\
\text { Engaged } \\
\text { Married }\end{array}$ & $\begin{array}{c}182 \\
16 \\
2\end{array}$ & $\begin{array}{c}91.0 \\
8.0 \\
1.0\end{array}$ \\
\hline $\begin{array}{l}\text { Religion } \\
\text { Christianity } \\
\text { Muslim }\end{array}$ & $\begin{array}{c}175 \\
25\end{array}$ & $\begin{array}{l}87.5 \\
12.5\end{array}$ \\
\hline $\begin{array}{l}\text { Allowance(\$) } \\
<30 \\
31-60 \\
61-90 \\
91-120 \\
121-150 \\
151-180 \\
>180\end{array}$ & $\begin{array}{c}46 \\
73 \\
39 \\
26 \\
8 \\
5 \\
3\end{array}$ & $\begin{array}{r}23.0 \\
36.5 \\
19.5 \\
13.0 \\
4.0 \\
2.5 \\
1.5\end{array}$ \\
\hline $\begin{array}{l}\text { Course of study } \\
\text { Sciences } \\
\text { Social Science } \\
\text { Art } \\
\text { Medical Sciences } \\
\text { Education }\end{array}$ & $\begin{array}{c}79 \\
55 \\
22 \\
35 \\
9\end{array}$ & $\begin{array}{c}39.5 \\
27.5 \\
11.0 \\
17.5 \\
4.5\end{array}$ \\
\hline $\begin{array}{l}\text { Level of study } \\
\text { One } \\
\text { Two } \\
\text { Three } \\
\text { Four } \\
\text { Five }\end{array}$ & $\begin{array}{c}10 \\
35 \\
25 \\
109 \\
21\end{array}$ & $\begin{array}{l}5.0 \\
17.5 \\
12.5 \\
54.5 \\
10.5\end{array}$ \\
\hline
\end{tabular}




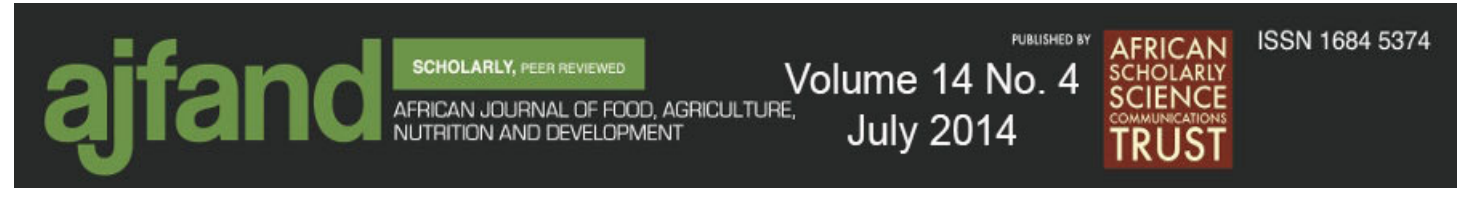

Table 2: Distribution of respondents based on knowledge about breastfeeding

\begin{tabular}{|l|l|l|l|l|}
\hline S/N & Knowledge statements & Agree & $\begin{array}{l}\text { I don't } \\
\text { know }\end{array}$ & Disagree \\
\hline 1 & Exclusive breastfeeding is for 12 months & $66(33)$ & $33(16.5)$ & $101(50.5)$ \\
\hline 2 & $\begin{array}{l}\text { Exclusive breastfeeding can serve as a means of child } \\
\text { spacing }\end{array}$ & $58(29.0)$ & $47(23.5)$ & $86(43.0)$ \\
\hline 3 & Exclusive breastfeeding involves giving of water & $50(25.0)$ & $38(19.0)$ & $112(56.0)$ \\
\hline 4 & $\begin{array}{l}\text { Exclusive breastfeeding involves feeding with infant } \\
\text { formula }\end{array}$ & $33(16.5)$ & $25(12.5)$ & $142(71.0)$ \\
\hline 5 & Colostrum contains antibodies & $18(9.0)$ & $44(22)$ & $138(69.0)$ \\
\hline 6 & $\begin{array}{l}\text { I can exclusively breast feed my child even if I am HIV- } \\
\text { positive }\end{array}$ & $27(13.5)$ & $55(27.5)$ & $118(59.0)$ \\
\hline 7 & Breastfeeding will help to improve my health & $22(11.0)$ & $60(30.0)$ & $118(59.0)$ \\
\hline 8 & Breastfeeding will enhance parent-child intimacy & $7(3.5)$ & $18(9.0)$ & $175(87.5)$ \\
\hline 9 & $\begin{array}{l}\text { Exclusively breast feed child develops a strong immune } \\
\text { system than those feed with formula }\end{array}$ & $8(4.0)$ & $21(10.5)$ & $171(85.5)$ \\
\hline
\end{tabular}

*percentage in parenthesis 


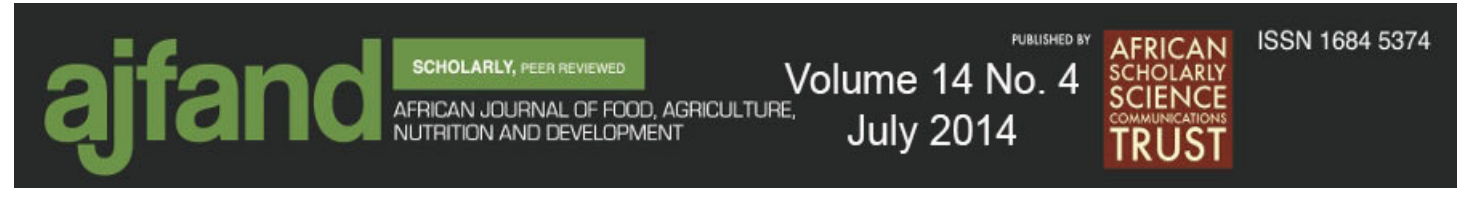

Table 3: Attitude toward breastfeeding

\begin{tabular}{|c|c|c|c|c|c|c|}
\hline $\mathbf{S} / \mathbf{N}$ & Attitudinal Statements & $\begin{array}{l}\text { Strongly } \\
\text { Agree }\end{array}$ & Agree & $\begin{array}{l}\text { I don't } \\
\text { know }\end{array}$ & Disagree & $\begin{array}{l}\text { Strongly } \\
\text { Disagree }\end{array}$ \\
\hline 1. & $\begin{array}{l}\text { I will exclusively breast feed my } \\
\text { child }\end{array}$ & $2(1.0)$ & $8(4.0)$ & $10(5.0)$ & $64(32.0)$ & $116(58.0)$ \\
\hline 2. & $\begin{array}{l}\text { I can only breast feed if I did not } \\
\text { have enough money for formula }\end{array}$ & $3(1.5)$ & $11(5.5)$ & $13(6.5)$ & $89(44.5)$ & $84(42.0)$ \\
\hline 3. & $\begin{array}{l}\text { I will combine breastfeeding } \\
\text { with infant formula }\end{array}$ & $31(15.5)$ & $92(46.0)$ & $28(14.0)$ & $34(17.0)$ & $15(12.5)$ \\
\hline 4. & $\begin{array}{l}\text { Exclusive breastfeeding is a } \\
\text { waste of time }\end{array}$ & $7(3.5)$ & $5(2.5)$ & $13(6.5)$ & $55(27.5)$ & $120(60.0)$ \\
\hline 5. & $\begin{array}{l}\text { Baby should be given breast } \\
\text { milk on request }\end{array}$ & $48(24.0)$ & $60(30.0)$ & $26(13.0)$ & $39(19.5)$ & $27(13.5)$ \\
\hline 6. & I cannot breast feed in public & $27(13.5)$ & $52(26.0)$ & $45(22.5)$ & $40(20.0)$ & $36(18.0)$ \\
\hline 7. & $\begin{array}{l}\text { Exclusive breastfeeding is an } \\
\text { outdated fashion }\end{array}$ & $6(3.0)$ & $6(3.0)$ & $9(4.5)$ & $70(35.0)$ & $109(54.5)$ \\
\hline 8. & $\begin{array}{l}\text { Children looking healthy should } \\
\text { not be breastfed }\end{array}$ & $3(1.5)$ & $1(0.5)$ & $4(2.0)$ & $56(28.0)$ & $129(64.5)$ \\
\hline 9. & $\begin{array}{l}\text { Immunization can prevent } \\
\text { infection instead of exclusive } \\
\text { breastfeeding }\end{array}$ & $5(2.5)$ & $13(6.5)$ & $41(20.5)$ & $91(45.5)$ & $51(25.5)$ \\
\hline
\end{tabular}

*percentage in parenthesis 


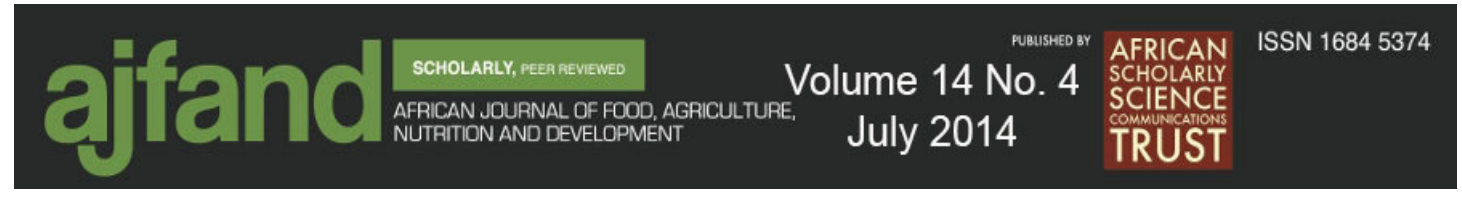

Table 4: Distribution of respondents based on intending practice of exclusive breastfeeding

\begin{tabular}{|c|c|c|}
\hline Intending practice & Frequency(200) & Percentage (\%) \\
\hline $\begin{array}{l}\text { Initiation of breastfeeding } \\
0-6 \text { hour } \\
7-10 \text { hour } \\
11-15 \text { hour } \\
\text { After first day }\end{array}$ & $\begin{array}{c}130 \\
23 \\
4 \\
43\end{array}$ & $\begin{array}{c}65.0 \\
11.5 \\
2.0 \\
21.5\end{array}$ \\
\hline $\begin{array}{l}\text { Prelacteal feeding } \\
\text { Concoction } \\
\text { Water }\end{array}$ & $\begin{array}{c}2 \\
20\end{array}$ & $\begin{array}{c}1.0 \\
10.0\end{array}$ \\
\hline $\begin{array}{l}\text { Exclusive breastfeeding after birth } \\
\text { Yes } \\
\text { No }\end{array}$ & $\begin{array}{c}\text { I80 } \\
20\end{array}$ & $\begin{array}{l}90.0 \\
10.0\end{array}$ \\
\hline $\begin{array}{l}\text { Duration of exclusive breastfeeding } \\
\text { 3months } \\
6 \text { months } \\
\text { 1year } \\
\text { 2years } \\
\text { No exclusive breastfeeding }\end{array}$ & $\begin{array}{l}22 \\
80 \\
50 \\
28 \\
20\end{array}$ & $\begin{array}{l}11.0 \\
40.0 \\
25.0 \\
14.0 \\
10.0\end{array}$ \\
\hline $\begin{array}{l}\text { Main reason for not exclusively } \\
\text { breastfeeding } \\
\text { Job } \\
\text { Time } \\
\text { Health }\end{array}$ & $\begin{array}{c}10 \\
4 \\
6\end{array}$ & $\begin{array}{l}50.0 \\
20.0 \\
30.0\end{array}$ \\
\hline $\begin{array}{l}\text { Termination of breastfeeding } \\
\text { 3months } \\
6 \text { months } \\
\text { 1year } \\
2 \text { years }\end{array}$ & $\begin{array}{c}10 \\
33 \\
101 \\
56\end{array}$ & $\begin{array}{c}5.0 \\
16.5 \\
50.5 \\
28.0\end{array}$ \\
\hline $\begin{array}{l}\text { Main reason for termination of } \\
\text { breastfeeding } \\
\text { Job } \\
\text { Health } \\
\text { Education } \\
\text { Age of child } \\
\text { Weaning } \\
\text { To reduce intimacy } \\
\text { Eating habit }\end{array}$ & $\begin{array}{c}12 \\
108 \\
47 \\
11 \\
12 \\
5 \\
5\end{array}$ & $\begin{array}{c}3.5 \\
54.0 \\
23.5 \\
3.0 \\
3.5 \\
1.0 \\
1.0\end{array}$ \\
\hline
\end{tabular}




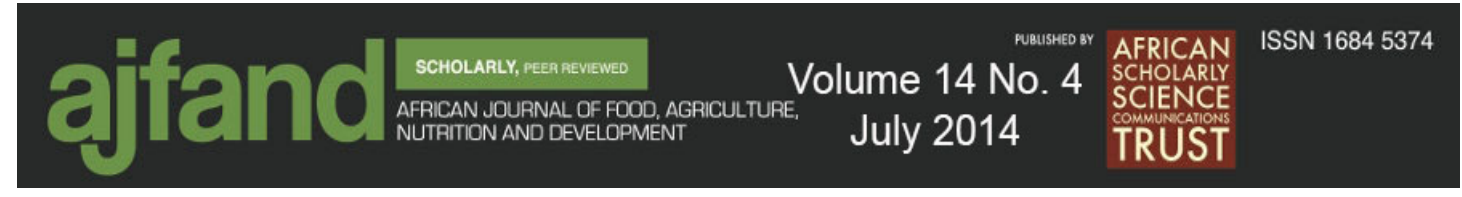

\begin{tabular}{|l|c|c|}
\hline Breastfeeding style & 125 & 62.5 \\
Demand & 75 & 36.4 \\
Fixed & & \\
\hline Reason for timing of feeding & 5.3 \\
Job & 15 & 20.0 \\
Education & 3 & 4.0 \\
Substitute & 16 & 21.3 \\
Time & 17 & 22.7 \\
Hunger & 14 & 18.7 \\
Health & 6 & 8.0 \\
Eating habit & & \\
\hline
\end{tabular}

Table 5: Management of exclusive breastfeeding at work

\begin{tabular}{|l|c|c|}
\hline Management & Frequency(200) & Percentage (\%) \\
\hline Management of exclusive breastfeeding at & & \\
work & 32 & 16.0 \\
Expression & 28 & 14.0 \\
Feeding at fixed time & 26 & 13.0 \\
Excuse at work & 1 & 0.5 \\
Mixed feeding & 9 & 4.5 \\
Exclusive breastfeeding impossible & 104 & 52.0 \\
Don't know & & \\
\hline Use of expressed milk & 84 & 42.0 \\
Yes & 69 & 34.5 \\
No & 47 & 23.5 \\
Don't know & & \\
\hline Reason for not feeding expressed breast & 1 & 1.5 \\
milk & 5 & 7.3 \\
Job & 2 & 2.9 \\
Education & 3 & 4.3 \\
Time & 25 & 36.3 \\
Status & 29 & 42.0 \\
Health & 4 & 5.7 \\
Contamination & & \\
Dislike & & \\
\hline
\end{tabular}




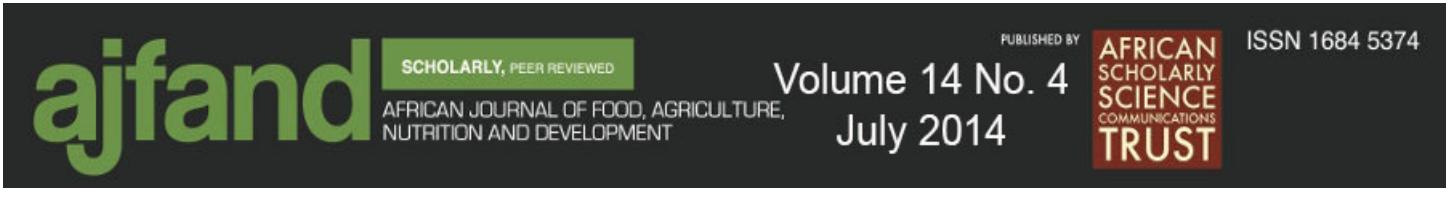

Table 6: Influencing on breastfeeding decision

\begin{tabular}{|l|l|l|}
\hline *Factors & Frequency & Percentage \% \\
\hline Mother & 51 & 24.8 \\
Mother-in-law & 36 & 17.5 \\
Husband & 71 & 34.5 \\
Friends & 21 & 10.2 \\
Job & 112 & 54.4 \\
Social status & 26 & 12.6 \\
Education & 40 & 19.4 \\
Health & 123 & 59.7 \\
Inadequate milk & 40 & 19.4 \\
\hline
\end{tabular}

*Multiple responses

Table 7: Frequency distribution of attitude, knowledge and characteristics of respondents

\begin{tabular}{|l|l|l|l|l|l|l|l|l|}
\hline \multirow{2}{*}{ Variables } & \multicolumn{3}{|c|}{ Attitude (\%) } & \multicolumn{1}{c|}{$\begin{array}{c}\text { P } \\
\text { value }\end{array}$} & \multicolumn{2}{c|}{$\begin{array}{c}\text { Knowledge (\%) } \\
\text { value }\end{array}$} \\
\cline { 2 - 9 } & $\begin{array}{l}\text { Negati } \\
\text { ve }\end{array}$ & Indifference & Positive & & Low & Average & High & \\
\hline Age(years) & & & & & & & & \\
$15-20$ & 1.6 & 25.0 & 73.4 & & 6.3 & 53.1 & 40.6 & \\
$21-25$ & 1.8 & 24.8 & 73.4 & 0.000 & 6.4 & 52.3 & 41.3 & 0.000 \\
$26-30$ & 0.0 & 28.6 & 71.4 & & 0.0 & 71.4 & 28.6 & \\
\hline Course of study & & & & & & & & \\
Sciences & 2.5 & 24.1 & 73.4 & & 7.6 & 54.5 & 37.9 & \\
Social Science & 1.8 & 22.3 & 70.9 & & 7.1 & 56.3 & 36.6 & \\
Art & 0.0 & 31.8 & 68.2 & 0.000 & 4.6 & 54.5 & 40.9 & 0.000 \\
Medical Sciences & 0.0 & 17.1 & 82.9 & & 0.0 & 45.7 & 54.3 & \\
Education & 0.0 & 22.2 & 77.8 & & 11.1 & 66.7 & 22.2 & \\
\hline Family type & & & & & & & & \\
Monogamous & 1.4 & 25.3 & 73.5 & 0.007 & 6.9 & 51.6 & 41.5 & 0.002 \\
Polygamous & 2.8 & 25.7 & 71.5 & & 2.8 & 62.8 & 34.4 & \\
Others & 0.0 & 0.0 & 100.0 & & 0.0 & 100.0 & 0.0 & \\
\hline
\end{tabular}




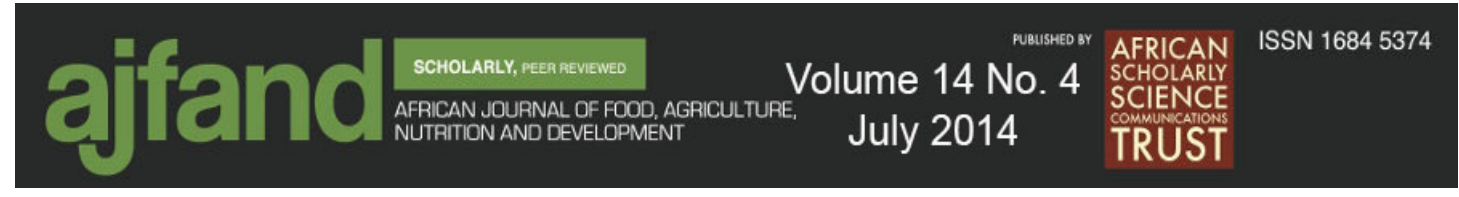

\section{REFERENCES}

1. Jones G, Steketee R, Black R, Bhutta Z and S Morris The Bellagio Child Survival Study Group. How many child deaths can we prevent this year? Lancet. 2003; 362(19):65-71.

2. Stuebe A The Risks of Not Breastfeeding for Mothers and Infants. Rev Obstet Gynecol. 2009; 2(4): 222-231.

3. Chantry $\mathbf{C}$, Howard $\mathbf{C}$ and $\mathbf{P}$ Auinger Full breastfeeding duration and associated decrease in respiratory tract infection in US children. Pediatrics. 2006; 117: 425-432.

4. Sadauskaitė-Kuehne V, Ludvigsson $\mathbf{J}$, Padaiga $\check{Z}$, Jašinskienė $\mathbf{E}$ and $\mathbf{U}$ Samuelsson Longer breastfeeding is an independent protective factor against development of type 1 diabetes mellitus in childhood Diabetes/Metabolism Research and Reviews 2004 20(2): 150-157.

5. UNICEF. Nigerian Demographic and Health Survey. National Population Commission. Federal Republic of Nigeria; 2008.

6. Ogbonaya $\mathbf{R}$ and $\mathbf{M}$ Aminu Nigeria: North-West Battling Malnutrition, Child and Maternal Mortality. This Day. 2009 www.allafrica.com . Retrieved on 01/02/2013.

7. UNICEF. Tracking Progress on Child and Maternal Nutrition; 2009

8. Agho KE, Dibley MJ, Odiase JI and SM Ogbonmwan Determinants of exclusive breastfeeding in Nigeria. BMC Pregnancy Childbirth. 2011;11(2) doi:10.1186/1471-2393-11-2.

9. Al-Ayed IH Mothers' knowledge of child health matters: Are we doing enough? J Family Community Med. 2010; 17(1): 22-28.

10. Papinczak TA and CT Turner An analysis of personal and social factors influencing initiation and duration of breastfeeding in a large Queensland maternity hospital. Breastfeeding Review. 2000; 8(1): 25-33. 


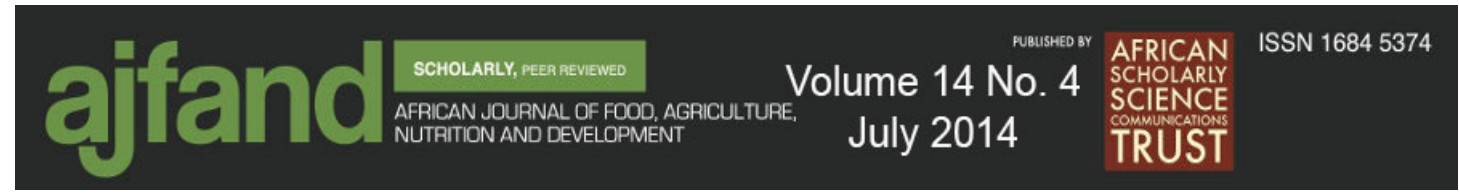

11. Chezem J, Friesen $\mathbf{C}$ and $\mathbf{J}$ Boettcher Breastfeeding knowledge, breastfeeding confidence, and infant feeding plans: effects on actual feeding practices. Journal of Obstetric, Gynecologic \& Neonatal Nursing. 2003; 32(1):40-47.

12. Kong SKF and DTE Lee Factors influencing decision to breast feed. Journal of AdvancedNursing. 2004; 46: 369-379.

13. Chambers JA, Mclnnes RJ, Hoddinott $\mathbf{P}$ and EM Alder A systematic review of measures assessing mothers' knowledge, attitudes, confidence and satisfaction towards breastfeeding. Breastfeeding Review. 2007; 15(3):17-25.

15. Forster DA, McLachlan HL and $\mathbf{J}$ Lumley Factors associated with breastfeeding at six months postpartum in a group of Australian women. International Breastfeeding Journal. 2006; 1:18. doi:10.1186/1746-4358-118.

16. Jiang H, Li M, Yang D, Wen LM, Hunter C He G and X Qian Awareness, Intention, and Needs Regarding Breastfeeding: Findings from First-Time Mothers in Shanghai, China Breast feed Med. 2012; 7(6):526-34.

17. Donath S and LH Amir Relationship between prenatal infant feeding intention and initiation and duration of breastfeeding: a cohort study. Acta Paediatrica. 2003; 92(3):352-356.

18. Arora Samir, Cheryl McJunkin, Julie Wehrer, Phyllis Kuhn Major Factors Influencing Breastfeeding Rates: Mother's Perception of Father's Attitude and Milk Supply. Pediatrics. 2000106 (5): e67.

19. Shirima R, Gebre-Medhin $\mathbf{M}$ and $\mathbf{T}$ Greiner Information and socioeconomic factors associated with early breastfeeding practices in rural and urban Morogoro, Tanzania Acta Pñ diatr 2001 90: 936- 942.

20. Muchina EN and PM Waithaka Relationship between breastfeeding practices and Nutritional status of children aged 0-24 months in Nairobi, Kenya African Journal of Food, Agriculture, Nutrition and Development. 2010; 10 (4): 2358-2378.

21. WHO. The optimal duration of exclusive breastfeeding: a systematic review. Geneva: World Health Organization. WHO/NHD/01.08;WHO/FCH/CAH/01.23, 2001. 


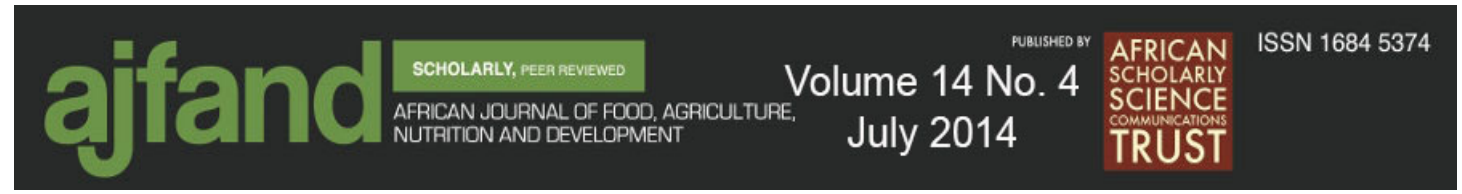

22. WHO. The optimal duration of exclusive breastfeeding. Report of an expert Consultation. Geneva. Switzerland. WHO. 2001.

23. Wen LM, Baur LA, Rissel C, Alperstein G and JM Simpson Intention to breast feed and awareness of health recommendations: findings from first-time mothers in southwest Sydney, Australia International Breastfeeding Journal. 2009; 4:9 doi: 10.1186/1746-4358-4-9.

24. Mukuria AG, Kothari MT and $\mathbf{N}$ Abderrahim Infant and Young Child Feeding Updates. Calverton, Maryland, USA: ORC Macro 2006.

25. Dubois $\mathbf{L}$ and $\mathbf{M}$ Girard Social determinants of initiation, duration and exclusivity of breastfeeding at the population level. The results of a longitudinal study of child development in Quebec (ELDEQ 1998-2002), Canadian J Public Health. 2003; 94(4):300-305. 